\title{
TERAPI REBUSAN AIR DAUN SIRIH PADA IBU HAMIL DENGAN PENGELUARAN CAIRAN PERVAGINAM BERUPA KEPUTIHAN DENGAN DI KLINIK PRATAMA PUTRI ASIH TAHUN 2020
}

\author{
Rina Yulviana, Sri Mayang \\ STIKes Hang Tuah Pekanbaru \\ Email : rinayulviana@htp.ac.id \\ Email : srim53753@gmail.com
}

\begin{abstract}
Leucorrhoea is one of the discomforts of pregnant women. Leucorrhoea is excess discharge from the vagina which is sometimes accompanied by itching, pain, burning sensation of pubic lips, often accompanied by a foul odor. Leucorrhoea if left alone can be a problem in the fetus such as, babies born prematurely or babies born with low weight. This problem can be helped through maintaining genetic hygiene, such as changing your underwear every time it gets wet. This case report aims to provide comprehensive and sustainable midwifery care through a midwifery management approach and document the care that has been given to pregnant women using betel leaf boiled water for 3 days which was carried out at the Putri Asih Primary Clinic on 15 September - 18 September 2020. It can be concluded that betel leaf can overcome leucorrhoea by giving as much as 3 times a day with 10 betel leaves for one use, for 3 days using betel leaf can reduce vaginal discharge and itching. After doing this research, the researchers found several pregnant women who had not kept genetalia clean. It is expected that pregnant women should always maintain genetic hygiene such as changing their underwear if they are wet, and doing the betel leaf water boiling technique to reduce vaginal discharge.
\end{abstract}

Keywords: Midwifery Care, Pregnant Women, Betel Leaf

\begin{abstract}
ABSTRAK
Keputihan merupakan salah satu ketidaknyamanan pada ibu hamil, Keputihan adalah keluarnya cairan berlebih dari vagina yang terkadang disertai rasa gatal, nyeri, rasa panas dibibir kemaluan, kerap disertai bau busuk. Keputihan jika di biarkan dapat menjadi masalah pada janin seperi ,bayi lahir premature atau bayi lahir dengan berat rendah. Masalah tersebut dapat dibantu melalui menjaga kebersihan genetalia,seperti mengganti pakaian dalam setiap kali basah. Laporan kasus ini bertujuan untuk melakukan asuhan kebidanan secara menyeluruh dan berkesinambungan melalui pendekatan manajemen kebidanan serta mendokumentasikan asuhan yang telah diberikan pada ibu hamil dengan teknik rebusan air daun sirih selama 3 hari yang di laksanakan di Klinik Pratama Putri Asih pada tanggal 15 September - 18 September 2020. Dapat di simpulkan bahwa daun sirih dapat mengatasi keputihan dengan pemberian sebanyak 3x sehari dengan 10 lembar daun sirih untuk satu kali pemakaian, selama 3 hari memakai daun sirih dapat mengurangi keputihan dan rasa gatal. Setelah di lakukan penelitian ini peneliti menemukan beberapa ibu hamil yang belum menjaga kebersihan genetalia. Diharapkan kepada ibu hamil untuk selalu menjaga kebersihan genetalia seperti mengganti celana dalam jika basah, dan melakukan teknik rebusan air daun sirih untuk mengurangi keputihan.
\end{abstract}

Kata kunci $\quad$ : Asuhan Kebidanan, Ibu Hamil ,Daun Sirih 


\section{PENDAHULUAN}

Kehamilan sebagai suatu proses yang terjadi antara perpaduan sel sperma dan ovum sehingga terjadi konsepsi sampai lahirnya janin, lamanya hamil normal adalah 280 hari atau 40 minggu dihitung dari haid pertama haid terakhir (HPHT) . Kehamilan dibagi dalam 3 periode yaitu trinester pertama dari konsepsi sampai 3 bulan, trimester kedua dari bulan keempat sampai 6 bulan, trimester ketiga dari bulan ketujuh sampai 9 bulan. (Wiknjosastro (2009)

Kehamilan menimbulkan beberapa ketidaknyamanan pada ibu hamil, salah satu ketidaknyamanan yang sering dirasakan adalah keluarnya cairan yg berlebih dari kemaluan seperti keputihan, keputihan tersebut ada bersifat fisiologis dan patologis. Keputihan yang bersifat fisiologis pada ibu hamil yaitu keputihan yang disebabkan karena peningkatan hormon estrogen dan progesteron. Keputihan yang bersifat patologis pada ibu hamil yaitu keputihan yang timbul karena infeksi dari jamur, bakteri dan virus. Keputihan patologis merupakan tanda dari adanya kelainan alat repoduksi sehingga jumlah, warna, dan baunya perlu diperhatikan.

Upaya mengatasi keputihan dapat dilakukan dengan cara farmakologi maupun non farmakologi. Upaya dengan farmakologi antara lain dengan pemberian obat obatan. Sedangkan non farmakologi antara lain melalui minum herbal seperti kunyit, dan rebusan air daun sirih (Membasuh ) .

Asuhan yang diberikan pada ibu hamil dengan keluhan keputihan yang bersifat fisiologis dapat diberikan asuhan agar tidak menjadi keputihan patologis. Salah satu asuhan yang dapat diberikan adalah Terapi Rebusan Daun Sirih yaitu mengajarkan ibu untuk membasuh vagina dengan cara yang benar, dari gerakan depan ke belakang, menganjurkan ibu untuk mengganti celana dalam setiap kali jika basah atau setelah BAB atau BAK, dan membersihkan dengan Rebusan Air Daun Sirih, memeritahu ibu untuk memperhatikan kebersihan lingkungan dengan membersihkan bak mandi, ember, menara air dan bibir kloset dengan antiseptik untuk menghindari berkembangbiak nya kuman, menganjurkan ibu untuk memakai pakaian dalam dari bahan katun dan mudah menyerap dan menganjurkan ibu untu meningkatkan daya tahan tubuh dengan makan buah dan sayur (Wiknjsastro,2009) dan (Hani, 2011)

Hasil penelitian yang dilakukan oleh Farida Zubier et al (2010 hal 11), menunjukan bahwa penggunaan ekstrak 
daun sirih hingga satu minggu dapat mengurangi keluhan keputihan pada ibu hamil dengan mengurangi jumlah lendir tanpa mempengaruhi keputihan, sehingga reaktif aman untuk mengurangi keputihan pada ibu hamil. Daun sirih dapat dijadikan alternatif pengobatan untuk penyakit-penyakit yang disebabkan seperti candida albicans yang merupakan penyebab keputihan patologis. Hal ini didukung oleh hasil penelitian Nurul Rahmah dan Aditya Rahman 2010), menunjukkan bahwa ekstrak daun sirih pada semua konsentrasi (20\%-100\%) dapat menghambat pertumbuhan sel Candida albicans (Ula and Liunesi 2018)

$$
\text { Berdasarkan survei yang }
$$
dilakukan oleh penulis pada tanggal 09 sampai 29 desember 2019 di Klinik Pratama Putri Asih 3 dari 20 ibu hamil yang datang ke klinik mengalami keputihan .

\section{METODE KASUS}

Metode laporan ini adalah studi kasus dengan latar belakang asuhan kebidanan pada ibu hamil dengan permasalahan keputihan. Pada studi kasus dilakukan wawancara dari anamnesis dan berlanjut dengan memberikan asuhan sampai evaluasi dan berlanjut memberikan asuhan sampai evaluasi dan dokumentasi. Studi kasus ini yaitu
Asuhan Kebidanan pada ibu hamil dengan pelaksanaan Rebusan Air Daun Sirih di Klinik Pratama Putri Asih.

\section{HASIL STUDI KASUS}

\section{A. Kajian 1}

Kunjungan pertama dilakukan di rumah pasien pada tanggal 15 September 2020 pukul 13.00 wib.

1. Pengkajian Data Subjektif

- Ny. D Uk 24 minggu,mengeluh keputihan nya Ibu mengatakan ada pengeluaran cairan dari vagina cair dan sedikit jumlah nya, Ibu mengatakan mengganti celana dala 3 kali sehari, namun tidak mengganti celana dalam setiap kali jika basah maupun lembab dan cara membasuh vagina dari arah belakang kedepan.

- Ibu mengatakan merasa gatal dan ada bintik merah di daerah genetalia.

2. Pengkajian Data Objektif keadaan umum ibu baik, tekanan darah 110/80 mmHg, denyut nadi $82 \mathrm{x} / \mathrm{i}$, pernafasan $21 \mathrm{x} / \mathrm{i}$, suhu 36,5 ${ }^{\circ} \mathrm{C}$, pada pemeriksaan kelopak mata ibu tidak pucat, konjungtiva merah muda, sklera putih, pola makan $3 \mathrm{x}$ sehari, pola istirahat tidur siang 2-3 jam ,tidur malam 7-8 jam perhari, eliminasi 
BAK 4-5 kali sehari, BAB 1x

sehari, anogenetalia terdapat keputihan yang merah dan gatal di vagina, kebersihan baik, TFU sepusat,imunisasi TT tidak lengkap .

3. Assement

Ny. D G1 PI A0 UK 24 minggu K/U ibu dan janin baik, janin hidup, tunggal, imunisasi TT tidak lengkap, Djj dalam batas normal .

4. Plan

a. Informasikan hasil pemeriksaan

b. Memberitahu ibu tentang nutrisi

c. Memberitahu ibu tentang istirahat

d. Memberitahu ibu tentang eliminasi

e. Memberitahu ibu tentang kebersihan genetalia

f. Memberitahu ibu tentang imunisasi TT

g. Memberitahu ibu tentang terapi rebusan daun sirih

\section{Implementasi}

a. beritahu ibu hasil pemeriksaan bahwa k/u ibu baik, ttv dalam batas normal.

b. Pola makan

Anjurkan ibu untuk makan sayuran, buah buahan, dan makan nasi yang lebih dari biasa nya atau sebelum hamil, makanan yang bergizi dan tidak mengandung yang menyebabkan keputihan.

c. Pola istirahat

Anjurkan ibu untuk istirahat yang cukup agar tidak mudah kelelahan

d. Eliminasi

Beritahu ibu untuk tidak menahan $\mathrm{BAK}$ atau BAB .

e. Kebersihan

Anjurkan ibu untuk menjaga kebersihan diri,terutama di genetalia. Dengan cara jangan memakai pakaian dalam yang lembab membasuh vagina dengan cara yang benar.

f. Imunisasi TT

Beritahu ibu untuk ke klinik menanyakan temtang imunasisi lanjut

g. Asuhan daun sirih

h. Anjurkan ibu untuk melakukan teknik rebusan Air Daun Sirih untuk mengatasi kepitihan, dengan cara membasuh vagina dengan rebusan daun sirih 3x sehari selama 1 minggu

\section{PEMBAHASAN}

1. Data Subjektif

Berdasarkan hasil kunjungan pertama Ny.D tanggal 15 September 2020 jam 13.00 WIB ibu mengeluh 
keputiha nya kental warna putri susu,terdapat bintik merah. Pada kunjungan kedua tanggal 18 september 2020 jam 12.00 WIB ibu mengatakan keputihan sudah cair berwarna bening,bintik merah berkurang setelah diberikan Terapi Air Daun sirih.

Hasil penelitian yang dilakukan oleh Hoirina diperoleh dari 3 ibu hamil (20\%) tidak mengalami keputihan, 12 ibu hamil (80\%) mengalami keputihan dengan kriteria 6 ibu hamil (40\%) mengalami keputihan fisiologis, 6 ibu hamil (40\%) mengalami keputihan patologis dan diperoleh data dari hasil wawancara pada responden didapatkan keputihan disertai dengan rasa gatal dan iritasi pada area kewanitaan.

Dari hasil asuhan yang telah di berikan selama 2 kali kunjungan dengan selang waktu 3 hari di dapatkan hasil yang di peroleh penulis dan perubahan keputihan kepada ibu, bawah keputihan sudah tidak kental lagi,warna nya sudah bening, bintik merah sudah berkurang dan ibu tidak memakai pantyliner lagi.
Hasil penelitian yang di lakukan oleh Kustanti (2017), menunjukan bahwa penggunaan rebusan daun sirih hijau efektif dalam menurunkan kejadian keputihan pada ibu hamil. Beberapa konten yang terkandung dalam minyak esensial dari daun sirih dihasilkan oleh minyak terbang (betiephenol), seskuiterpen, pati, diastase, gula dan zat tanin dan alkohol yang memiliki kuman mematikan, antioksidasi dan fungisida dan anti jamur.

\section{Data Objektif}

Data objektif yang ditemukan pada kunjungan pertama pada tanggal 15 september 2020 yaitu keadaan umum ibu baik, tekanan darah 110/80 mmHg, denyut nadi 82 $\mathrm{x} / \mathrm{i}$, pernafasan $21 \mathrm{x} / \mathrm{i}$, suhu $36,5^{\circ} \mathrm{C}$, pada pemeriksaan kelopak mata ibu tidak pucat, konjungtiva merah muda, sklera putih, pola makan $3 x$ sehari, pola istirahat tidur siang 2-3 jam ,tidur malam 7-8 jam perhari, eliminasi BAK 4-5 kali sehari, BAB 1x sehari, anogenetalia terdapat keputihan yang merah dan gatal di vagina, kebersihan baik, TFU sepusat,imunisasi TT tidak lengkap. Dari hasil pemeriksaan setelah di lakukan terapi rebusan air daun sirih 
pada kunjungan ke 2, hasil yang di peroleh penulis yaitu, ada perubahan pada keputihan ibu seperti tidak kental lagi, tidak memakai pantyliner dan bintik merah mulai berkurang.

3. Plan

Pada asuhan pada kunjungan pertama penulis memberikan penkes kepada ibu untuk selalu menjaga kebersihan genetalia seperti selalu ganti celana dalam bila celana dalam basah, mengatur pola istrirahat agar tidak mudah kelelahan. Memberitahu ibu untuk konsul lagi tentang imunisasi TT ke petugas kesehatan untuk melakukan imunisasi TT lanjut. Melakukan Rebusan Air Daun sirih $3 x$ dalam sehari selama 1 minggu

Menurut (Andareto, 2015) kandungan dari daun sirih hijau (piper betle.l )sangatlah bagus untuk pengobatan salah satunya adalah keputihan pada ibu hamil. Ada beberapa kandungan yang terdapat didalam daun sirih hijau diantaranya minyak astiri, hidroksikavicol, kavicol, kavibetol, allyprokatekol, eugenol, caryophyllelen, cyneole, candinene, diastse, pati, terpennena, sesquiterpena, phenyil propane, tanin, gula, dan anti jamur.

Penelitian lain yang dilakukan oleh Zubeir et al (2010), menunjukan bahwa penggunaan ekstrak daun sirih 10 lembar daun sirih hingga satu minggu dapat mengurangi keluhan keputihan pada ibu hamil dengan mengurangi jumlah lendir tanpa mempengaruhi flora normal, sehingga reaktif aman untuk mengurangi keputihan pada ibu hamil (Ula and Liunesi 2018)

\section{KESIMPULAN}

Dari asuhan yang diberikan kepada Ny.D pada tanggal 15 September 20020 dan 18 September 2020 dilakukan 2 kali kunjungan dengan rentang waktu 3 hari dengan terapai rebusan air daun sirih pada ibu hamil. Setelah dilakukan asuhan selama 2 kali kunjungan tersebut maka hasil yang didapat pada kajian terakhir yaitu keputihan ibu sudah mulai berkurang, sudah encer dan berwarna bening, bintik merah sudah mulai berkurang dan tidak memakai pantyliner lagi.

\section{SARAN}

1. Bagi Klinik Pratama Putri Asih

Diharapkan kepada penyedia layanan asuhan kebidanan (Klinik) agar dapat memberikan penyuluhan kepada ibuibu hamil untuk selalu menjaga kebersihan genetalia, dan menyediakan leflet tentang keputihan 
pada ibu hamil, meningkatkan pengetahuan tentang cara Rebusan Air Daun Sirih untuk mengatasi keputihan.

2. Bagi STIKes Hang Tuah Pekanbaru Diharapkan agar dapat menambah referensi mengenai pendokumentasian kebidanan pada ibu hamil, agar mahasiswa dapat meningkatkan pengetahuan dan keterampilan pada ibu

Hamil serta membuat pendokumentasian asuhan kebidanan tersebut dengan baik dan benar.

3, Bagi Mahasiswa

Diharapkan agar dapat memberikan asuhan pelayanan dan pemantauan pada ibu hamil yang mengalami keputihan saja.

\section{DAFTAR PUSTAKA}

Candrasari, Anika, M. Amin Romas, and ovi rizky astuti. 2011. "uji daya antimikroba ekstrak etanol daun sirih hijau (piper crocatum ruiz \& pav.) Terhadap pertumbuhan staphylococcus aureus atcc 6538, eschericia coli atcc 11229 dan candida albicans atcc 10231 secara in vitro." Biomedika 5 (1): 9-16.3

Keputihan, and Sman Pekanbaru. 2014. "Tentang Rebusan Daun Sirih Dalam Mengatasi,” 2014-17

Ula, Zumrotul, and Derthi Ferina Liunesi. 2018. "Pengaruh Penggunaan Air Rebusan Daun Sirih Hijau (Piper Betle L.) Terhadap Flour Albus Pada Wanita Usia Subur Di PMB Afah Fahmi, A.Md. Keb Surabaya Tahun 2018." Infokes: Info Kesehatan 8 (2): 39-44.

eputihan, and Sman Pekanbaru. 2014. "Tentang Rebusan Daun Sirih Dalam Mengatasi,”2014-17.

B A B, and Tinjauan Pustaka. n.d. "Priscilla_Jessica_22010112130175 _Lap._KTI_Bab2,”8-36.

Title." Journal keputihan of Physical Chemistry B 8 (1): 28-48.

Kocjan, R. 1998. "Analysis of Some Metal Ions Using Silica Gel Modified with Acid Orange 7 as a Sorbent." Hungarian Journal of Industrial Chemistry 26 (4): 263-67. 